Int. J. Morphol.,

28(2):433-438, 2010 .

\title{
The Incidence of the Foramen Thyroideum in the South African Population
}

\author{
Incidencia del Foramen Tiroideo en la Población de Sudáfrica
}

L. Ramsaroop; K. Hurrinarain; P. Partab \& K. S. Satyapal

RAMSAROOP, L.; HURRINARAIN, K.; PARTAB, P. \& SATYAPAL, K. S. The incidence of the foramen thyroideum in the South African population. Int. J. Morphol., 28(2):433-438, 2010.

SUMMARY: The foramen thyroideum is described as an occasional opening existing in one or both laminae of the thyroid cartilage which may or may not contain a neurovascular component. Foramen thryoideum was first described in the literature by Segond in 1847. Some authors consider its existence a structural variation rather than an anomaly, with classical texts of anatomy providing little detail when describing this foramen. This study was undertaken to investigate the incidence and characteristics of the foramen thyroideum in the South African population. A total of 80 formalin fixed cadaveric laryngeal specimens (obtained from the Department of Clinical Anatomy, University of KwaZulu-Natal, South Africa) were dissected. Larynges were dissected with the aid of a Stemi DV 4 light microscope. The incidence, location, dimensions and contents of the foramen thyroideum were recorded. The horizontal and vertical extent of each foramen was measured with a digital caliper. Six of the $80(7.5 \%)$ specimens examined had distinctly identifiable foramina. Five of the six cases (4 male, 1 female) displayed bilateral foramina (6.3\%), with one case ( 1 female) of a unilateral foramen (1.3\%). Of the larynges that had bilateral foramina, a single case presented with two foramina on the same (right) thyroid lamina. A total of twelve foramina were observed. Gender distribution of foramen thyroideum was: male: right 5 , left 4 ; female: right 2 , left 1 . Preceding investigators of the foramen thyroideum have rightly indicated that awareness of its presence is of paramount importance in order to preserve the structures that traverse it and also to comprehensively treat or contain laryngeal cancer.

KEY WORDS: Thyroid; Foramen; Larynx; Variation.

\section{INTRODUCTION}

Foramen thyroideum (FT) has been described as an occasional opening existing in one or both plates of the thyroid cartilage which may or may not contain a neurovascular component (Zemlin et al., 1984). Although first described in 1847 by Segond (Leon et al., 1997), it remains a contentious issue as some consider its existence a routine structural variation rather than an anomaly (Ortug $e t$ $a l ., 2005)$, with classical texts of anatomy not delving into great detail when providing an account on FT (Friel, 1974; Williams et al., 1989; McMinn, 1990).

Previous investigations have yielded either unilateral or bilateral occurrence of the FT (Leon et al.; Ortug et al.) that extend over a wide range (Leon $e t$ al.) with reports of more than one foramen on the same thyroid lamina (Ortug $e t$ $a l$. ) also having been recorded. The literature also demonstrates cases in which the FT functions as a unique conduit for branches of the superior laryngeal nerve (Tanaka et al., 1997) as well as the superior laryngeal artery and vein (Zemlin et $a l$.). It has been hypothesized that the foramen may also provide a pathway for adenocarcinoma and pyriform recess or transglottic tumors (Kirchner et al., 1989) but remains as resistant to laryngeal cancer as the rest of the thyroid lamina.

To our knowledge, no investigations systematically evaluating the incidence of the FT or comparing their characteristics and emphasizing their clinical significance have been previously published on the South African population, thus highlighting a need for such a study.

\section{MATERIAL AND METHOD}

The study comprised a sample size of 80 formalin fixed laryngeal specimens (a total of 160 thyroid laminae) 
which were sourced with approval from the State Mortuary, Gale Street, Durban, South Africa and the research conducted at the Department of Clinical Anatomy, University of KwaZulu-Natal. The sample size was decided upon bearing in mind a statistically significant cell size as well as access and availability of specimens. Ethical approval for this study was granted by the Institutional Biosafety and Research Committee of the University of KwaZulu Natal. The sex distribution of the specimens were 46 male (58\%) and 34 were female $(42 \%)$. The age range was between 43 years to 81 years for male and 55 years to 73 years for female. Standard anatomical micro-dissection techniques were employed to dissect the larynges with the aid of a Stemi DV 4 light microscope (Carl Zeiss Inc, Germany). Specimens that had been previously dissected, deformed due to trauma or had evidence of pathology were excluded from the study. The incidence, location, dimensions and contents of the foramen thyroideum were recorded. The horizontal and vertical extent of each foramen was measured by means of a digital caliper (Digitronic caliper; Wolpert Europe; Maastricht, Netherlands). Statistical analysis was conducted with the statistical package SPSS using the Binomial Two Proportion Test (for differences in counts).

\section{RESULTS}

Incidence. Six of the $80(7.5 \%)$ specimens examined had distinctly identifiable foramina (Table I). Five of the six cases (4 male, 1 female) displayed bilateral foramina (6.3\%) (Fig. 1), with one case (1 female) of a unilateral foramen $(1.3 \%)$ (Fig. 2). Of the larynges that had bilateral foramina, a single case presented with two foramina on the same (right) thyroid lamina, separated by only a thin band of cartilage

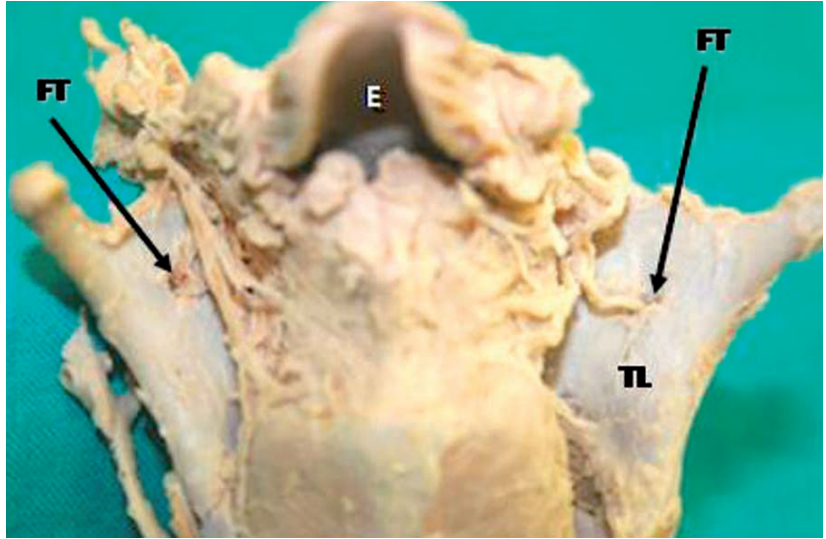

Fig. 1. Posterior view of thyroid lamina illustrating bilateral FT with anastomotic connection between external and the internal laryngeal nerves. E=Epiglottis.

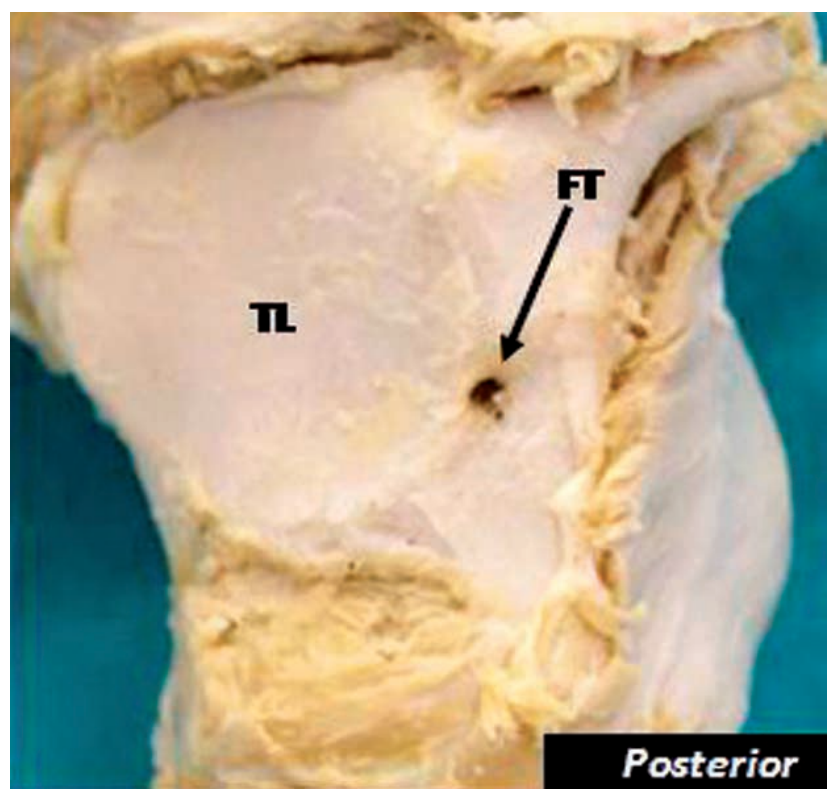

Fig. 2. FT in left thyroid lamina on oblique line.

Table I. Incidence of foramen thyroideum in the literature reviewed.

\begin{tabular}{|c|c|c|c|c|}
\hline Author(s) & Population group & Sample Size & Number & Incidence $(\%)$ \\
\hline Gruber (1876) & German & 170 & 71 & 48 \\
\hline Dilworth (1921) & British & 23 & 4 & 17.3 \\
\hline Waldeyer (1927) & German & 100 & 55 & 55 \\
\hline Roncallo (1948) & Italian & 57 & 3 & 5.2 \\
\hline Guerrier \& Prioton (1954) & French & 94 & 24 & 26 \\
\hline Keen \& Wainwright (1958) & South African & 133 & 23 & 17 \\
\hline Afifi (1970) & French & 16 & 7 & 44 \\
\hline Jelisiejew \& Szmurlo (1972) & Polish & 484 & 184 & 38 \\
\hline Lang et al. (1984) & German & 22 & 6 & 27 \\
\hline Zemlin et al. (1984) & American & 66 & 22 & 33 \\
\hline Kirchner et al. (1989) & American & 190 & 86 & 45 \\
\hline Leon et al. (1997) & Spanish & 90 & 28 & 31 \\
\hline He et al. (1999) & French & 50 & 1 & 2 \\
\hline Ortug et al. (2005) & Turkish & 50 & 6 & 12 \\
\hline Cicekcibasi et al. (2008) & Turkish & 40 & 5 & 12.5 \\
\hline Ramsaroop et al. (2009) & South African & 80 & 6 & 7.5 \\
\hline
\end{tabular}


(Fig. 3). A total of twelve foramina were observed. The incidence of FT in individual sexes were as follows: male: right 5, left 4; female: right 2, left 1 (Table II). No statistically significant differences between sexes or sides were noted.

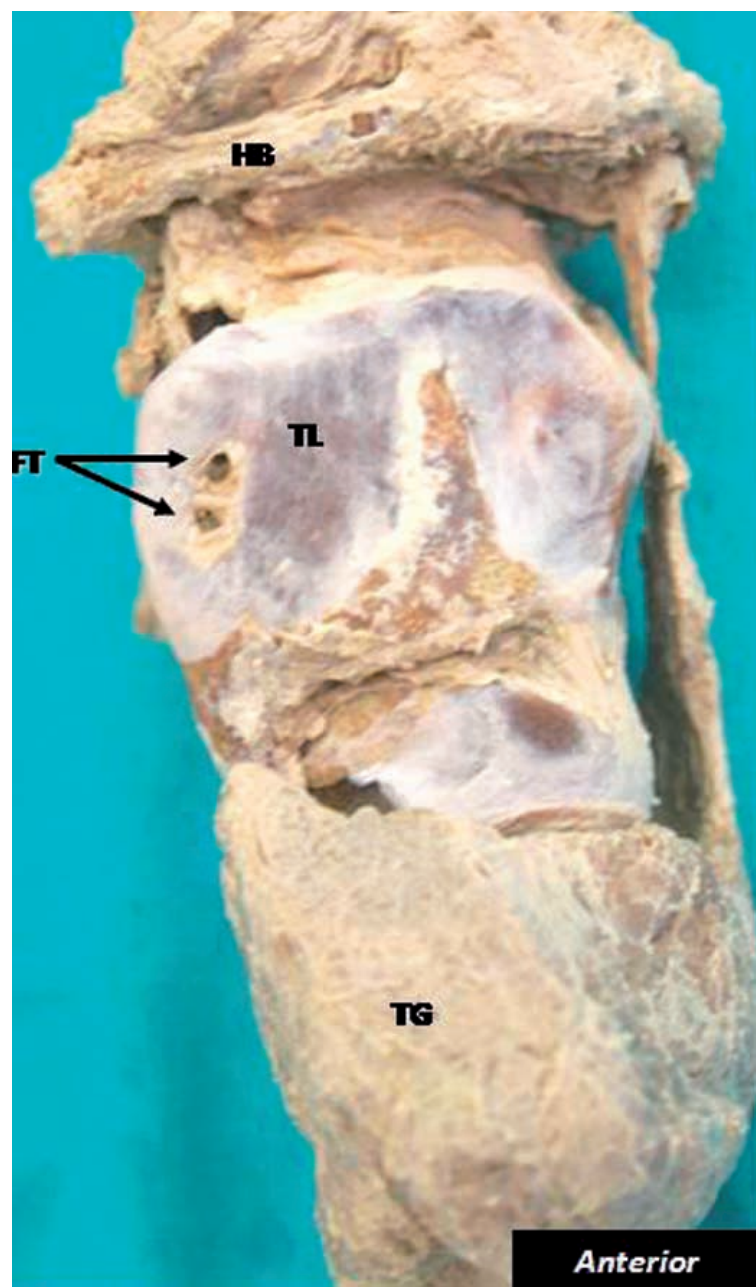

Fig. 3. Lateral view of double FT in the right thyroid lamina. $\mathrm{HB}=$ Hyoid bone, $\mathrm{TG}=$ Thyroid gland.
Morphology. Six foramina were oval in shape; while six were almost perfectly round in shape. No statistically significant differences were noted.

Location. The locations of the foramina were identified in relation to the oblique line of the thyroid lamina. Eight of the foramina were situated anterior to the oblique line (Fig. 4) with a mean distance of $1.8 \mathrm{~mm}$ (range: $0.93 \mathrm{~mm}$ $2.32 \mathrm{~mm}$ ); two were located posterior to the oblique line (Fig. 3 ) with a mean distance of $1.9 \mathrm{~mm}$ (range: $1.5 \mathrm{~mm}-2.4 \mathrm{~mm}$ ) and two were located on the oblique line (Fig. 2) (Table III). The single case of double foramina on the right thyroid lamina was located posterior to the oblique line, facing posteriorly (Fig. 3).

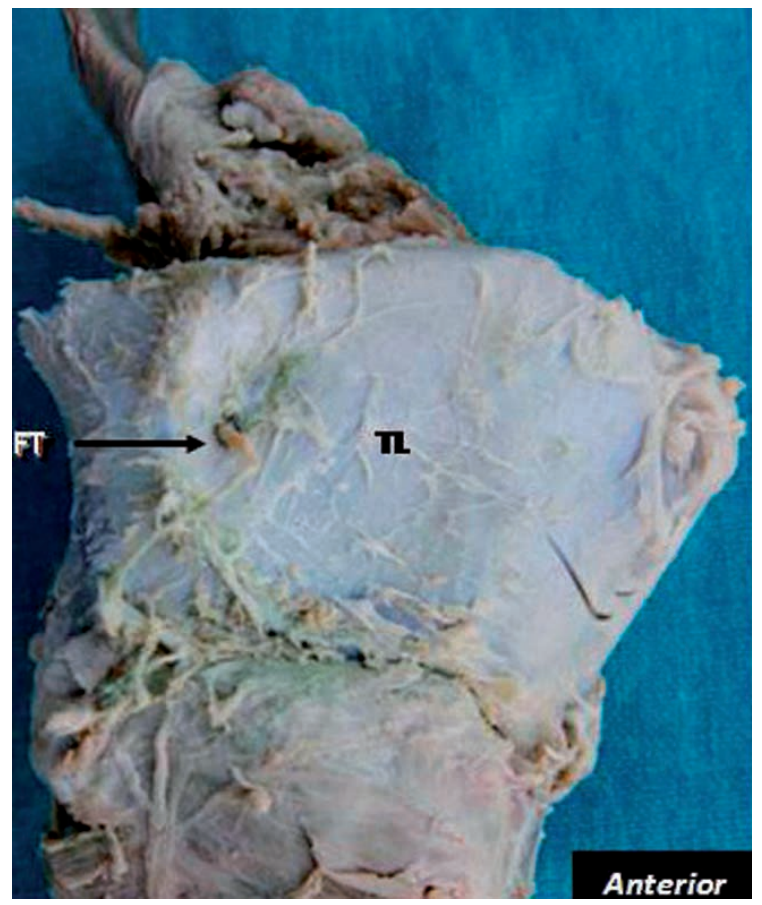

Fig. 4. Lateral view of FT situated anterior to oblique line. Note: Exit of internal laryngeal nerve via FT. TL=Thyroid lamina, FT=Foramen thyroideum.

Table II. Sex distribution of foramen thryoideum in the literature reviewed.

\begin{tabular}{lccc}
\hline Author & Male & Female & Unknown \\
\hline Zemlin et al. $(1984)$ & 8 & 13 & 1 \\
Ortug et al. (2005 & 6 & 0 & 0 \\
Ramsaroop et al. $(2009)$ & 9 (5 right, 4 left $)$ & 3 (2 right, 1 left) & 0 \\
\hline
\end{tabular}

Table III. Location of foramen thyroideum in relation to oblique line $(n=12)$. Please note: Authors describing FT in relation to the oblique line only, without providing mean distances, is shown in brackets

\begin{tabular}{lcc}
\hline Location on thyroid lamina & Mean distance (mm) & Range (mm) \\
\hline Anterior to oblique line ( $\mathrm{n}=8)$ (Ortug et al. 2005) & 1.8 & $0.9-2.3$ \\
Posterior to oblique line (n=2) (Keen \& Wainwright,1958; Zemlin & & $1.5-2.4$ \\
et al., 1984; Leon et al., 1997) & 1.9 & - \\
On oblique line ( $\mathrm{n}=2)$ & - & - \\
\hline
\end{tabular}


Measurements. The mean horizontal and vertical diameters $(\mathrm{mm})$ of the FT was found to be $2.9 \mathrm{~mm}$ and $3.1 \mathrm{~mm}$; and $2.8 \mathrm{~mm}$ and $2.6 \mathrm{~mm}$ on the right and left sides, respectively (Table IV).

Contents. All twelve foramina contained an anastomotic connection between the external laryngeal nerve and the internal laryngeal nerve. In addition, a neural connection between the external laryngeal nerve and the recurrent laryngeal nerve via the FT was observed in one case. In the thyroid cartilage displaying two foramina on the right side, two separate connections between the external laryngeal and internal laryngeal nerves via their respective foramina were noted. In two cases FT was also traversed by the superior laryngeal artery.

Table IV. Measurements of foramen thyroideum.

\begin{tabular}{lcccc}
\hline Diameters $(\mathrm{mm})$ & \multicolumn{2}{c}{ Horizontal } & \multicolumn{2}{c}{ Vertical } \\
\hline \multirow{3}{*}{ Mean } & Right & Left & Right & Left \\
\cline { 2 - 5 } Min & 2.9 & 2.8 & 3.1 & 2.6 \\
Max & 2.3 & 2.3 & 2.5 & 2.2 \\
\hline
\end{tabular}

Table V. Size of foramen thryoideum in literature reviewed. *Measurements in individual sexes not available.

\begin{tabular}{lc}
\hline Author (s) & Measurement range (mm) \\
\hline Gruber (1876) & $0.5-9^{*}$ \\
Afifi (1970) & $2.5^{*}$ \\
Lang et al. (1984) & $2.5-4^{*}$ \\
Zemlin et al. (1984) & $0.45-6.5$ (female); 0.5-6 (male) \\
Ramsaroop et al. (2009) & Horizontal : 2.3-4.3 (female); 2.2-4.1 (male) \\
& Vertical: 2.2-3.2 (female); 2.2-3.9 (male) \\
\hline
\end{tabular}

\section{DISCUSSION}

Previous studies have indicated a wide range in incidence of FT of between 2\% to 55\% (Table I). Our data illustrates an incidence of $7.5 \%$ which compares with only one previous investigation - viz. Roncallo (1948). Furthermore, only two previous studies describe the sex distribution (Table II); Zemlin et al. noted a higher incidence in females whereas Ortug et al. and our study recorded the opposite.

Developmentally, two theories have been proposed to explain the derivation of the FT. The first is the branchial origin where the FT is considered to be an incomplete union of the cartilaginous elements of the fourth and sixth pharyngeal arches which give rise to the thryoid lamina. The second is the neurovascular theory which postulates that the presence of a vessel or nerve in the lamina of the thyroid cartilage during the embryonic period resulting in failure of chondrification, thus the formation of the FT (Leon et al.); however consideration should be given to the possibility that failure of coalescence of the fourth and sixth branchial arches and the presence of abnormal nervous or mesenchymal growth appear to be two processes that are intimately connected with one another and that failure on either end could lead to abnormal growth in either direction (Leon et $a l$.). Our data supports the latter theory where all twelve foramina contained a neural component which consisted of an anastomotic connection between the external and internal laryngeal nerves. These results compare favourably with that of Leon et al. In two of the twelve cases, the FT contained the superior laryngeal artery confirming reports by Zemlin et al.

In contrast to the study conducted by Ortug et al. on the Turkish population, our study revealed a higher incidence of bilateral FT (6.3\%) compared to their study of $2 \%$. In addition, a unilateral foramen in our study was noted in only 1 case $(1.3 \%)$ on the right side, which differs from previous researchers (Afifi, 1970; Zemlin et al.; Leon et al.) who record that unilateral FT appear to be located more frequently on the left side.

Our study also records the presence of a double FT on the right side, with the upper FT being larger than the lower. These results compare favorably with those of Gruber (1876) as well as Leon et al. who reported two and three cases of double FTs, respectively. 
The measurements of the size of the FT compare favorably with that of Afifi and Lang et al. (1984) (Table V). However, only the study conducted by Zemlin et al. described the measurements of FT in males and females, which differed to our study which documents the diameter ranges for males and females of FT viz. horizontal diameter $2.2 \mathrm{~mm}-4.1 \mathrm{~mm}$ and $2.3 \mathrm{~mm}-4.3 \mathrm{~mm}$; and vertical diameter $2.2 \mathrm{~mm}-3.9 \mathrm{~mm}$ and $2.2 \mathrm{~mm}-3.2 \mathrm{~mm}$, respectively (Table V).

Preceding investigators of the FT have rightly indicated that awareness of its presence is of paramount importance in order to preserve the structures that traverse it and also to comprehensively treat or contain laryngeal cancer (Ortug et al.). From the results obtained in this study, it can be clearly demonstrated that the incidence of the FT in the South African population is less frequent, and with no gender dimorphism as compared to studies conducted in European population groups; however the location, size and contents are comparable and its clinical importance should not be neglected. Iatrogenic injury of the inferior laryngeal nerve, terminal portion of the recurrent laryngeal nerve (Reidenbach, 1995), is one of the most crucial concerns during thyroid surgery where paralysis of the vocal cords may be an inadvertent complication. This causes significant phonatory, respiratory and psychological problems that may impact on patient lifestyle (Dilworth, 1921). The operating surgeon, therefore, should exercise added vigilance when performing interventional surgery in order to prevent avoidable injury.

RAMSAROOP, L.; HURRINARAIN, K.; PARTAB, P. \& SATYAPAL, K. S. Incidencia del foramen tiroideo en la población de Sudáfrica. Int. J. Morphol., 28(2):433-438, 2010.

RESUMEN: El foramen tiroideo se describe como una apertura ocasional existente en una o ambas láminas del cartílago tiroides, la cual puede o no contener un componente neurovascular. El foramen tiroideo fue descrito por primera vez en la literatura por Segond en 1847. Algunos autores consideran su existencia como una variación estructural y no una anomalía, los textos clásicos de anatomía proporcionan pocos detalles al describir este foramen. Este estudio se realizó para investigar la incidencia y características del foramen tiroideo en la población Sudafricana. Fueron disecados 80 especímenes cadavéricos de larínge fijados con formalina (obtenidos del Departamento de Anatomía Clínica de la Universidad de KwaZulu-Natal, Sudáfrica). Las laringes fueron disecadas con la ayuda de un microscopio de luz Stemi DV 4. La incidencia, localización, dimensiones y contenido del foramen tiroideo fueron registradas. La extensión horizontal y vertical de cada foramen se midieron con un caliper digital. Seis de los 80 (7,5\%) especímenes examinados tenían foramen tiroideos claramente identificables. Cinco de los seis casos (cuatro hombres y una mujer) mostraron forámenes bilaterales (6,3\%), y un caso (una mujer) foramen unilateral $(1,3 \%)$. De las laringes que presentaron forámenes bilaterales, un solo caso presentó dos forámenes en la misma lámina del cartílago tiroides (derecha). La distribución por sexo del foramen tiroídeo en hombres fue 5 derechos y 4 izquierdos, mientras que en mujeres 2 derechos y 1 izquierdo. Los resultados indican que el conocimiento de la presencia del foramen tiroideo es de vital importancia para preservar las estructuras que lo atraviesan y también para el tratamiento de integral o contención del cáncer de laringe.

PALABRAS CLAVE: Tiroides; Foramen; Laringe; Variación.

\section{REFERENCES}

Afifi, A. B. Etude sur l'orifice du cartilage thyroide et son contenu nerveux. Arch. Anat. Histol. Embryol. (Strasb), 53:273-88, 1970.

Cicekcibasi, A. E.; Keles, B. \& Uyar, M. The morphometric development of the fetal larynx during the fetal period. Int. J. Pediatr. Otorhinolaryngol., 72(5): 683-91, 2008.

Dilworth, T. F. The Nerves of the Human Larynx. J. Anat., 56(1):48-52, 1921.

Friel, J. P. Dorland's Illustrated Medical Dictionary. Philadelphia, WB Saunders, 1974.

Gruber, W. Ueber das foramen in den laminae cartilago thyroidea. Virchows Arch., 66:455-7, 1876.
Guerrier, Y. \& Prioton, J. B. Le foramen thyroidien. J. Franc. d'Otorhinol-laryngol., 3:22-4, 1954.

He, X.; Ye, C.; Carrat, X. \& Traissac, L. Etude anatomique du foramen thyroidien du larynx chez l'homme: á propos de 100 dissections. Rev. Laryngol. Otol. Rhinol. (Bord), 120 (2): 127-9, 1999.

Jelisiejew T, Szmurbo J. Structural variations of the thyroid cartilage. Folia Morphol. (Warsz), 31:127-32, 1972.

Keen, J. A \& Wainwright, J. Ossification of the thyroid, cricoid and arytenoid cartilages. S. Afr. J. Labor Clin. Med., 4: 83-108, 1958.

Kirchner, J. C.; Kirchner, J. A. \& Sasaki, C. T. Anatomic foramina in the thryoid cartilage: incidence and 
implications for the spread of laryngeal cancer. Ann. Otol. Rhinol. Laryngol., 98(6):421-5, 1989.

Lang, J.; Fischer, K. \& Nachbauer, S. U’ber mabe, form und formvarianten der cartilagines thryoidea et cricoidca. Gegenbaurs Morph. Jahrb., 130:639-57, 1984.

Leon, X.; Maranillo, E.; Mirapeix, R. M.; Quer, M. \& Sañudo, J. R. Foramen Thyroideum: A comparative study in embryos, fetuses and adults. Laryngoscope, 107(8):114650, 1997.

McMinn, R. M. H. Last's Anatomy: Regional and Applied. 8 Ed. New York, Churchill Livingstone, 1990.

Ortug, C.; Gunduz, T. \& Sam, B. The incidence of foramen thyroideum in the Turkish population. Surg. Radiol. Anat., 27:491-4, 2005.

Reidenbach, M. M. Topographical relations between the posterior cricothyroid ligament and the inferior laryngeal nerve. Clin. Anat., 8:327-3, 1995.

Roncallo, P. Research about ossification and conformation of the thyroid cartilage in men. Acta Otolaryngol. (Stockh), 36:110-34, 1948.

Tanaka, S.; Shoumura, S.; Chen, H.; Nakatani, T. \& Mizukami, S. Aberrant branch of the superior laryngeal nerve passing through the thyroid foramen: a macroscopical study. Kaibogaku Zasshi, 72(4):251-6, 1997.

Williams, P. L.; Warwick, R.; Dyson, M. \& Bannister, L. H. Gray's Anatomy. 37 th Ed. New York, Churchill Livingstone, 1989.

Waldeyer, Z. Zur individual und Rassenanatomie des menschlichen kehlkopfes. Z. Morphol. Anthropol., 26:68-126, 1927.

Zemlin, W. R.; Simmom, A. \& Hammel, D. The frequency of occurrence of foramen thyroideum in the human larynx. Folia Phoniat., 36:296-300, 1984.
Correspondence to:

Professor KS Satyapal

Department of Clinical Anatomy

School of Medical Sciences, Faculty of Health Sciences

Westville Campus, College of Health Sciences

University of KwaZulu-Natal

Private Bag X54001, Durban 4001

SOUTH AFRICA

Telephone: + 27312607195

Fax: + 27312607890

Email: satyapalk@ukzn.ac.za

Received: 25-11-2009

Accepted: 11-03-2010 